\title{
VARGAS LLOSA: EL MAESTRO DE LOS ESCRITORES
}

\author{
Santiago Gamboa
}

En este ensayo se discuten las distintas maneras en que la obra de Mario Vargas Llosa está presente en el tejido literario latinoamericano actual. Se sostiene que su influencia en las nuevas generaciones es palpable en muchos aspectos, estilísticos y temáticos, y esto por su peculiar modo de escritura, por la compleja arquitectura de sus ficciones, por la labor militante y pedagógica que despliega en sus ensayos, los cuales incluyen reflexiones que, a pesar de haber sido escritas en diferentes épocas, siguen dando elementos para definir la

Santiago Gamboa (Bogotá, 1965). Escritor y periodista. Columnista del cotidiano El Espectador, de Colombia, también colabora para la revista mexicana Nexos. Estudió literatura en la Universidad Javeriana de Bogotá; en 1985 se licenció en filología hispánica por la Universidad Complutense de Madrid. En 1990 cursó estudios de literatura cubana en la Universidad de la Sorbona. Trabajó como periodista en la Agencia France Presse (AFP), en Radio Francia Internacional (RFI), y fue corresponsal en París del periódico El Tiempo de Bogotá, y corresponsal para el mismo diario en la guerra de los Balcanes y el conflicto de Argelia. Debutó como novelista con Páginas de vuelta (Norma, 1995; Mondadori, 1998). Luego vendrían Perder es cuestión de método (Norma y Mondadori, 1997) - llevada al cine en 2005 por el director colombiano Sergio Cabrera-, Vida feliz de un joven llamado Esteban (Ediciones B, 2000), Los impostores (Seix Barral, 2002) y El sindrome de Ulises (Seix Barral, 2005). Es también autor del libro de viajes Octubre en Pekín (2001). Ha sido diplomático en la delegación de Colombia ante la Unesco, en París, y Consejero cultural en la embajada de Colombia en India. Actualmente reside en Roma. Sangamboa@gmail.com. 
contemporaneidad de América Latina, en todos los órdenes - a veces incluso por oposición-, así como la figura del intelectual en el siglo XXI. Vargas Llosa, por todo esto, no es sólo un gran novelista — afirma Santiago Gamboa—, sino que ha sido elegido por muchos como un maestro.

\section{La tía Julia}

$\mathrm{D}$ ebió ser hacia 1979, con catorce años, cuando leí el primer libro de Vargas Llosa. Mis padres eran profesores de artes y antropología en la Universidad Nacional de Bogotá, y por supuesto grandes lectores, y antes de cada viaje de vacaciones - por lo general a fincas de amigos o a lugares con patrimonio artístico - tenían la costumbre de pasar por librerías y comprar una buena provisión de novedades, que iban a sumarse a los miles que ya tenían en la casa. Los escogían meticulosamente y nos pedían a mi hermano y a mí que hiciéramos lo mismo, y luego, durante el transcurso de las vacaciones, los intercambiábamos. Cada uno llevaba cuatro o cinco, de acuerdo a su voracidad, y al final podía decirse que todos leíamos todo.

La editorial en la que estaban editados la mayoría de los libros que leíamos en esos años era Seix Barral: volúmenes blancos con una foto en el centro, el arquero apuntando hacia lo alto, y un catálogo tan extraordinario que rápidamente la convirtió en mi editorial fetiche. Ahí estaban las novelas de Cabrera Infante, Onetti, Donoso, Sábato, Goytisolo, Fuentes, y por supuesto Vargas Llosa. Fue así que, enamorado de la carátula - un collage de imágenes- elegí en un paseo La tía Julia y el escribidor, que leí, o más bien devoré, creo, en un día y medio, y por haber sido ese mi primero, me quedó la costumbre de recomendarlo cuando alguien me pide consejo sobre cuál libro de Vargas Llosa leer para comenzar, pues a mi modo de ver tiene muchas cosas novedosas, sorpresivas, y una escritura tan fluida y francamente agradable que es imposible resistirse.

El Vargas Llosa de La tía Julia era ya un autor muy famoso y, por supuesto, consagrado, uno de los cuatro jinetes del boom al lado de Carlos Fuentes, Gabriel García Márquez y Julio Cortázar. En la contraportada de esta primera edición, de 1977, luce su célebre sonrisa, el 
rebelde mechón de pelo que cruza su frente y sus enormes dientes. Es uno de los autores más leídos del mundo occidental y uno de los más jóvenes. En ese momento tiene apenas 41 años, pero ya su currículum de escritor da vértigo: premio Biblioteca Breve en 1962 con La ciudad y los perros, y premio de la Crítica de 1963; en 1965 La casa verde, premio de la Crítica 1966 y Rómulo Gallegos en 1967. Y luego una seguidilla de premios aquí y allá, en las treinta o más lenguas a las que ha sido traducido, perteneciendo siempre y de pleno derecho a ese reducido y selecto club de "escritores internacionales", conocidos en todo el mundo occidental - y parte del oriental-, en el que la abrumadora mayoría son autores anglosajones.

Al releer La tía Julia años después - estudiando filología y literatura en Madrid, a los diecinueve años- descubrí algo que no había visto en mi primera lectura, y es que era la novela de un joven latinoamericano de clase media que quería ser escritor, luchando por desarrollar su vocación contra la adversidad del entorno. Exactamente lo que era yo: un joven latinoamericano de clase media que quería ser escritor. Lo que éramos todos los de mi generación en ese momento: jóvenes latinoamericanos que soñábamos con ser escritores. Y aunque el entorno fuera otro, también, de algún modo, luchábamos.

La tía Julia mostraba un camino posible, un ejemplo de alguien que persistió y defendió su vocación contra viento y marea y que, al final, logró imponerse. Un aguerrido y valiente escritor que experimentó las mismas dudas que vivíamos nosotros, que sintió la inseguridad y la baja estima, pero que mantuvo su deseo como una antorcha hasta que la convirtió en un fuego denso. Que se hizo las mismas preguntas y sintió esa mezcla de fascinación nerviosa y deseo de autoinmolación que lo acomete a uno cuando el virus de la literatura se le mete en la sangre, cuando uno está dispuesto a dar la vida por ella. Por eso, de un modo muy latinoamericano, siempre he creído que La tía Julia es una novela de formación, equivalente a lo que suponen en la literatura anglosajona Retrato del artista adolescente, de James Joyce, en la alemana Los cuadernos de Malte Laurids Brigge, de Rilke o La montaña mágica, de Mann, y en la española El árbol de la ciencia, de Pío Baroja.

En el caso de La tía Julia, es muy importante y sorpresivo que sea él mismo el personaje central de la historia - Marito-, el hecho de que haya usado su propia vida para escenificar el encuentro de una vocación y las mil y una artimañas que un joven escritor en ciernes en- 
cuentra para salirse con la suya a través de trabajos paralelos que cumplen con la doble función de alimentarlo — "trabajos alimenticios" - y de hacerle conocer mundos distintos y alejados a los de sus plácidas familias capitalinas. La tía Julia ejemplifica muy bien por qué los escritores de mi generación, y sin duda los más jóvenes, eligieron a Vargas Llosa como "maestro". Si uno mira en detalle, también en La ciudad y los perros, e incluso en Conversación en La Catedral, los protagonistas son jóvenes que están haciendo su entrada al mundo: el adolescente de La ciudad y los perros, el nihilista y descreído de Conversación. Tal vez por haber madurado tan rápido como escritor, Vargas Llosa utiliza protagonistas jóvenes, que además se le asemejan, que están en conflicto con el mundo, que buscan comprenderlo, amansarlo, adecuarse a él con pocas armas, fragilizados por sus anhelos literarios, enamoradizos y soñadores, en fin, jóvenes, y esto, en primer grado, tiene un efecto de cercanía con los lectores de las generaciones siguientes.

Vargas Llosa, por lo demás, siempre rechazó el calificativo de genio para un escritor. Una de las sensaciones más paralizantes que existen es considerar que los autores que uno admira, sus obras y todo lo que dicen o piensan, es dictado por una inspiración superior, una especie de magia que hace que personas como Borges, Rulfo, Cortázar o García Márquez, por citar sólo latinoamericanos, sean experiencias literarias que provienen de otros universos, tocados por la varita mágica de algún dios literario que les da el supremo don del talento, eso que para los románticos convertía a los artistas en seres resplandecientes, una suerte de raza iluminada y por lo tanto inalcanzable para el simple mortal.

Cuando empecé a escribir debía enfrentar a diario un terrible problema, y era el siguiente: lo que yo hacía, los textos que leía y releía en mis páginas a máquina — esto fue hacia 1985- eran tan dolorosamente lejanos de todo aquello que admiraba, tan pobres e incoloros - $\mathrm{e}$ insípidos e inodoros - que, muchas noches, desesperado y frustrado, decidía no escribir más y salir a vagar por las oscuras calles madrileñas, pues sólo si dejaba de escribir me parecía posible continuar soñando con ser escritor. Por su genialidad, Joyce, Proust o Kafka eran estrellas demasiado lejanas, así que lo mejor era caminar por ahí, fumar sin parar y transformarme en un espectro, a la espera de la muy improbable visita de alguna musa, de un gesto que permitiera reconocer algo de ese ansiado talento que tanto admiraba y anhelaba. Pero nada. Lo más común era el silencio, malhumorado y devastador. 
Vargas Llosa, en cambio, era el dios de los orfebres, de la literatura vista como un preciado don, sí, pero también como un látigo: ¡a trabajar! Todo es posible con disciplina, con rigurosidad; ésta no asegura nada, por supuesto, pero sin ella no se llega a ningún lado. De repente, con Vargas Llosa, se sugería la idea de un método: escribe y escribe, todos los días, no pares de escribir. A algún lado llegarás. Y más aún el novelista: la clase obrera de la literatura, el que debe escribir ocho horas diarias o más, a diferencia del poeta, que es la aristocracia, que no tiene la obligación de llegar al final de la página. Todo era posible con disciplina. Precisamente por haber escrito tanto sobre su proceso de aprendizaje, por haber revelado en sus ficciones sus dudas, frustraciones y bloqueos de aprendiz, y por haber hecho famosa esa frase de que sus libros eran " $10 \%$ de inspiración y $90 \%$ de transpiración"; por todo eso era una figura más cercana, más posible en términos estadísticos, más alcanzable. Una forma de decir: hay esperanza. Si trabajas duro y te entregas, puede que lo logres.

Por lo demás, Vargas Llosa nunca pregonó un estilo de vida específico para ser escritor. Esto es muy común en ciertos autores, sobre todo en los de corte romántico: creer que el modo en que ellos viven, descreídos, irreverentes, retadores, bohemios, nefelibatas, anárquicos, báquicos, hoscos, arbitrarios, solitarios, lucífugos, militantes, nocturnos, su actitud general ante la vida es la que deben adoptar y el modo en que deberían vivir los verdaderos escritores, los de raza, y que por ende ser escritor es pertenecer a esa selecta cofradía de renuncias, ritos y pactos de sangre al amanecer. Vargas Llosa, en esto, fue siempre todo lo contrario. El escritor es el que escribe y punto, y el buen escritor es el que escribe bien, viva como viva. Se vista como se vista. Uno no es mejor que otro por mantenerse alejado del sol en una mansarda húmeda, con la única compañía de una escultura de Poe o de un cuervo enjaulado. Los sufrimientos y vicisitudes de un escritor, nos sugiere Vargas Llosa, son secundarios. Lo importante son sus libros; sólo después, por curiosidad o fetichismo, su vida puede parecernos importante. Pero nunca al revés. ¿Es la literatura un modo de vida? Sin duda: la de quienes encontramos en los libros una armonía, una prosodia y un placer que no existe en el chato mundo real. Pero para ser escritor no es imprescindible adoptar un modo específico de vida, o considerar que tal actitud es la correcta - aunque tampoco está prohibido hacerlo-. Basta con escribir. Hay escritores con tendencia a legislar sobre esto, 
pero son sobre todo sus lectores, quienes los admiran, los que se vuelven radicales e intransigentes, acusando a diestra y siniestra al que no encaje en su modelo.

Recuerdo que en la atribulada universidad Complutense de Madrid de fines de los años ochenta, con la férrea politización estudiantil y el rechazo a las leyes de reforma universitaria del ministro socialista José María Maravall, que convertía las carreras humanísticas en minicarreras, milité con fuerza en un grupúsculo llamado KAI (Kolectivo Alternativo de Izquierdas), con el que nos tomamos varias veces la facultad y, sobre todo, un edificio del Consejo de Universidades, con su director incluido como rehén. En esas acaloradas charlas descubrí que para muchos Vargas Llosa era un fascista y un impostor, pero lo más curioso es que ninguno lo había leído. Les bastaba con verlo vestido de traje y corbata. No eran ni siquiera sus opiniones, ya muy controvertidas en ese entonces. Su imagen era suficiente. ¿Por qué? Para ellos, un verdadero escritor debía tener el pelo largo, sucio y enmarañado, barba descuidada, jeans y chaqueta de pana. Fue inútil decirles que era un gran novelista y que sus artículos de opinión, con ideas diferentes a las mías, me parecían mucho más estimulantes que las de otros con los que estaba de acuerdo. Cuando les recomendaba que lo leyeran, respondían: "¡Ni un duro al tío facha ese!?.

Vargas Llosa, reitero, sólo pregonaba la disciplina. No había que ser bohemio o irreverente, como los parnasianos, o romántico, como Lord Byron. La imagen que él proyectaba era la de un modesto trabajador, un tipo que, durante ocho horas diarias, está "atornillado a la máquina de escribir, como un forzado de la literatura", según lo describió su amigo Jorge Edwards. Y luego, al levantarse de su mesa de trabajo, vuelve a ser un ciudadano común y corriente, una persona más entre la gente, un transeúnte cualquiera.

\section{Una anécdota}

No me resisto a contar aquí una experiencia de la que tuve noticia cercana, con Vargas Llosa y un joven escritor colombiano, Antonio García, como protagonistas, y que es prueba tanto de la proverbial disciplina con la que encara su trabajo como de su enorme generosidad. Era el año 2004 y la Fundación Rólex, la de los relojes suizos, había convocado a una beca en el marco de su programa "Rolex Mentor \& 
Protégé Arts Initiative", para la cual se me invitó en calidad de prejurado, junto con Jorge Volpi, Alberto Fuguet y el editor Jorge Herralde. Nuestro cometido era elegir una terna de jóvenes escritores en lengua española, menores de 35 años, para que luego Vargas Llosa, nombrado "Mentor" por la Rolex, eligiera a uno y fuera su preceptor y maestro durante un año, acompañándolo en la escritura de un libro. La suerte quiso que Vargas Llosa eligiera al joven Antonio García, amigo mío, quien me contó paso a paso lo que fue su año de trabajo.

No quiero dar demasiados detalles —esto le correspondería hacerlo a Antonio-, pero lo que recuerdo es que, de entrada, Vargas Llosa le dio un lista de al menos 50 novelas que debía leer — en caso de que no las hubiera leído-y le impuso una férrea disciplina: los viernes Antonio debía enviar lo escrito durante la semana, de modo que Vargas Llosa leía el sábado, y el domingo hablaban y discutían por teléfono. De esas charlas se derivaban una serie de lineamientos: desarrollar escenas, dar más relieve a tal personaje, cambiar el punto de vista de un episodio. Para Antonio, que hasta ese momento había sido un escritor más bien lento, el inicio fue terriblemente difícil, al punto de sentirse casi en una escuela militar literaria, una suerte de Leoncio Prado para aprendices de novelista, pues cada charla con Vargas Llosa lo obligaba a escribir o reescribir en una semana un volumen de páginas que, antes, podía tomarle meses de trabajo. Como es lógico se fue adecuando e hizo todos los esfuerzos, pues Vargas Llosa nunca soltaba la cuerda, y con elegancia y afecto era implacable, hasta que logró acostumbrarlo al ritmo.

Como parte del programa, debían encontrarse personalmente más o menos cada tres meses, y el primero de esos encuentros fue en Londres. Allí Vargas Llosa lo fusiló con observaciones, referencias, consejos. Antonio no daba abasto para tomar nota. Se despedían una tarde y Vargas Llosa lo citaba al día siguiente con los cambios y desarrollos hechos. La segunda vez se vieron en París, y a pesar de que Antonio estaba ya algo acostumbrado, volvió a ser una verdadera maratón, a la que vino a sumarse algo insólito y es que Vargas Llosa, sorprendido de que Antonio no conociera París, decidió mostrarle a fondo la ciudad, y así lo llevó personalmente a cada uno de los sitios que él consideraba importantes para un escritor, le explicó y contó historias, lo llevó a todos los museos, a teatro, a conciertos, incluso al Folies Bergère y a los restaurantes más famosos, aquellos a los que iban Balzac o Victor 
Hugo - por supuesto jamás permitió que Antonio pagara un centavolo reprendió por no saber hablar francés y le hizo una lista de dos páginas con obras francesas imprescindibles, de modo que al cabo de una semana Antonio conocía mejor París que muchos de los que habíamos vivido en ella durante diez años. Al final, fruto de semejante oportunidad, Antonio publicó una excelente novela, Recursos humanos, que es increíblemente muy poco vargasllosiana, lo que demuestra hasta qué punto Vargas Llosa comprendió el lenguaje de Antonio y supo no sólo respetarlo sino además potenciarlo al máximo.

\section{El periodismo}

Regreso a La tía Julia para señalar otro aspecto, y es que aparte de ser una novela de formación, pareciera inaugurar un pequeño subgénero latinoamericano y es la novela del joven periodista que aprende las armas del oficio en alguna sección de un periódico o, como es el caso, de una redacción radial. Que yo recuerde, esta peripecia se repite en muchas novelas posteriores, caso de Tinta roja, de Alberto Fuguet, o de Los últimos días de La Prensa, de Jaime Bayly, por no citar más que dos casos. La tía Julia es el antecedente que marca la pauta: los jóvenes periodistas latinoamericanos de estas novelas sueñan con ser escritores. Trabajar entre rotativas, linotipos, noticias urgentes, crímenes, escándalos, papel carbón, redactores y fotógrafos, los hace sentirse cerca de la escritura, pero sobre todo de la vida que palpita en los rincones, en los vicios desesperados de las ciudades, en lo más banal, dulce o abyecto de la condición humana; les permite conocer de cerca la sociedad en la que viven, de forma transversal, mirar sus costuras y no limitarse a los guetos de las clases media y media alta de donde provienen.

Es importante constatar que en América Latina las generaciones de escritores posteriores al boom, de forma mayoritaria, han nacido y crecido en ciudades, y por lo tanto es la ciudad el espacio privilegiado de sus ficciones. Urbes felices o nerviosas, violentas, luminosas y frívolas, presuntuosas aldeas, cuna de todos los vicios. Ese magma es el terreno de la novela y también del periodismo. Las redacciones están en ciudades pobladas y nocturnas. Es una imagen del cine: un hombre observando las luces de la ciudad, con un cigarrillo en la boca, tecleando un informe que debe estar listo antes del amanecer. 
Esto revela otra profunda verdad y es que en América Latina el novelista suele recurrir al periodismo para ganarse la vida. La generación de Vargas Llosa dio ese cambio, pues hasta ese momento el escritor se la ganaba más bien con la abogacía. Antes, los aspirantes a escritores estudiaban derecho y trabajaban en despachos públicos, redactando demandas, transcribiendo audiencias o rellenando instancias de recurso en firmas de abogados. Los que tenían más suerte saltaban a la diplomacia, como Germán Arciniegas, Carlos Fuentes, Octavio Paz o Miguel Ángel Asturias. De los autores del boom, Vargas Llosa y García Márquez se ganaron la vida por un tiempo como periodistas, creando, diría yo, una verdadera escuela. Carlos Fuentes, tal vez con una economía más holgada desde sus inicios, tomó el camino de la docencia en universidades norteamericanas e inglesas, y practicó en paralelo el periodismo de opinión; Cortázar vivió de ser traductor en la Unesco hasta que sus libros le produjeron réditos suficientes para vivir.

Con Fuentes, García Márquez y Vargas Llosa, el periodismo de buena factura, la crónica escrita con arte, llegó a ser considerada un género literario. Y lo sigue siendo. García Márquez financia una Fundación de Nuevo Periodismo en Cartagena de Indias y ha declarado más de una vez que el periodismo es el "oficio más hermoso del mundo". De las obras de Vargas Llosa al menos seis volúmenes, un total de tres mil páginas, son artículos periodísticos. No es de extrañar que, tras esto, una gran mayoría de escritores latinoamericanos sean hoy columnistas en sus países o, los más jóvenes, críticos literarios en revistas especializadas o separatas de diarios. La huella del periodismo está ahí. También ocurre con frecuencia lo contrario: periodistas que dieron el salto a la novela, como Horacio Castellanos Moya o Leonardo Padura.

Esto tiene relación con otro aspecto que Vargas Llosa ha recalcado siempre y que muchos jóvenes escritores han heredado, y es la necesidad de que el novelista, el intelectual en general, no se aleje de una función crítica dentro de la sociedad en la que vive. Esa es su idea del compromiso, y esto, como es lógico, tiene que ver con el ejercicio del periodismo de opinión. Vargas Llosa lo dijo hace décadas con una frase bastante ingeniosa, "el escritor es el perpetuo aguafiestas", aquel que verá siempre el lado oscuro y pondrá el dedo en la llaga. Es su deber decirlo, denunciarlo, nos dice, pues al fin y al cabo la sociedad le da un estatuto especial, que es el de tener voz y ser escuchado, y por lo tanto el escritor debe responder con responsabilidad a ese privilegio. 
Y ahí está él con sus columnas participando en los debates políticos del Perú, de América Latina, de Europa, del mundo en general, consignando su punto de vista sobre guerras y tragedias, sobre lo divino y lo humano - más lo humano- y celebrando también, con generosidad, aquello del arte o la literatura que lo sorprende y entusiasma, e incluso, a una edad ya mayor, haciendo sesudos y comprometedores reportajes sobre Palestina, Yugoslavia o África, en los que prima el ojo del novelista para hacer comprensibles conflictos, enredos políticos, enfrentamientos tribales o religiosos a través de crónicas que agarran la realidad y la sacuden, la ordenan haciéndola comprensible y sutil a ojos del lector.

Esta función social o compromiso, este engagement que sin duda recibió de influencias francesas - puede que sea lo único que, con el tiempo, le haya dejado Sartre- está también presente en las nuevas generaciones de escritores, que a menudo, de forma un poco apresurada, han sido calificadas de apolíticas. No lo son en Colombia, ni en Chile, ni en México, casos que conozco, donde los escritores están siempre opinando, formando parte del debate, haciendo escuchar su voz, y no me cabe duda de que en la imagen que tienen de la obligación del escritor, está siempre muy presente la influencia de Vargas Llosa.

\section{La escritura}

Hay otro motivo por el que muchos escritores de mi generación vieron en Vargas Llosa a un "maestro", al menos en sus años de formación, y tiene que ver con el tipo de escritura. Es fácil comprobar que la prosodia de García Márquez es un camino sin salida para cualquiera que no sea él mismo. Su admirable tensión entre lírica y prosa, su perfecta sonoridad, su abundancia de imágenes, su bellísima hipérbole, son sencillamente irrepetibles, no admiten seguidores, y por eso quienes han incurrido en ese camino no pueden ser más que copistas o plagiarios. Y los ha habido - algunos muy exitosos- - Algo similar sucede con la obra de Borges y de Cortázar. Ellos, al igual que García Márquez, inventaron una escritura y la agotaron, la llevaron al límite.

Veamos algunos ejemplos.

Si alguien escribe "fatigó los corredores", sea quien sea, está copiando a Borges, lo mismo que en el uso de una adjetivación previa típica de la hipálage, caso de "unánime noche", "impetuoso film", "ar- 
dua etimología". También el verbo "inferir" ("Inferir de un libro...”), e incluso en su forma transitiva ("le infirió una taza de té"). Ni hablar en lo temático, donde Borges creó una estirpe de copistas que andan por el mundo inventando etimologías, encontrando "manuscritos apócrifos" y nuevas versiones de los Eddas.

En cuanto a García Márquez, la frase "mecidos por el sopor de la siesta" es propiedad suya, o giros del tipo: "su resuello sin alma de marido urgente"; el huracán de adjetivos de: "la ciudad despertó de su letargo de siglos con una tibia y tierna brisa de muerto grande y de podrida grandeza"; o lo estrepitoso de una imagen: "una tarde de enero habíamos visto una vaca contemplando el crepúsculo desde el balcón presidencial"; o la proverbial exageración: "los sauces babilónicos que habían sido transportados vivos desde el Asia Menor en gigantescos invernaderos de mar, con su propio suelo, su savia y su llovizna".

Igual con Cortázar, que incluye, entre otros, invención de palabras: "Apenas él le amalaba el noema, a ella se le agolpaba el clémiso y caían en hidromurias", o extrañas adjetivaciones: una mujer "toda talco y carita de parque japonés sábado a la noche", o una chaqueta "tan Liceo Francés, tan amiguitas contando secretos y canciones". Por supuesto que el estilo cortazariano está algo reducido al habla argentina, pero ha sido copiado en otros aspectos como la acumulación de expresiones en otros idiomas (Hélas!, putsch, plastic's age!), la enumeración caótica basada en filosofismos, discos de jazz, frases budistas, calles de Londres, París o Roma, una cierta atmósfera cosmopolita con citas de Lichtenberg y música de Coltrane o Chet Baker.

Vargas Llosa, en cambio, tiene una escritura diferente, menos impregnada. Cuando uno conoce a fondo su obra le parece que cierto tipo de giros son inconfundibles, incluso los signos de puntuación, pero lo son de un modo menos vistoso que en los casos anteriores. Veamos el principio de La tía Julia: "En ese tiempo remoto, yo era muy joven y vivía con mis abuelos en una quinta de paredes blancas de la calle Ocharán, en Miraflores. Estudiaba en San Marcos, Derecho, creo, resignado a ganarme más tarde la vida con una profesión liberal, aunque, en el fondo, me hubiera gustado más llegar a ser un escritor". Este párrafo, bastante neutro, podría haber sido escrito por cualquier autor, pues no contiene un uso específico de símiles, adjetivación, ni siquiera un ritmo muy preciso; es casi el lenguaje al desnudo, la descripción de unos hechos, una crónica. Veamos el principio de una de sus novelas más des- 
lumbrantes, Conversación en La Catedral: "Desde la puerta de La Crónica Santiago mira la avenida Tacna, sin amor: automóviles, edificios desiguales y descoloridos, esqueletos de avisos luminosos flotando en la neblina, el mediodía gris. ¿En qué momento se había jodido el Perú? Los canillitas merodean entre los vehículos detenidos por el semáforo de Wilson voceando los diarios de la tarde y él echa a andar, despacio, hacia la Colmena. Las manos en los bolsillos, cabizbajo, va escoltado por transeúntes que avanzan, también, hacia la plaza San Martín. Él era como el Perú, Zavalita, se había jodido en algún momento. Piensa: ¿en cuál?". La pregunta por el Perú definió toda una época y se convirtió en una marca literaria vargasllosiana, pero de nuevo las palabras son neutras, el estilo es directo, descriptivo, acumulativo; crea una imagen mental, casi cinematográfica; inicia, sí, un uso muy particular de los dos puntos, un regodeo en torno a la interrogación, pero ya se ve que lo que define su estilo no es tanto un tipo de frase o una adjetivación, como una concepción global de la novela; no el arco o el baldaquino o la ventana, sino la arquitectura completa, y por esto Vargas Llosa sí admite seguidores, es posible aprender a escribir leyéndolo con atención, es decir con lápiz y papel, pues cada una de sus novelas podría ser vista como un desafío técnico resuelto que de inmediato pone de relieve asuntos clave de la narrativa como la velocidad, el punto de vista, las transiciones.

Leyendo sus novelas con cuidado, uno comprende su mecánica e incluso puede ver cómo logra ciertos efectos. El entrelazamiento de tiempos, el estilo indirecto libre, el ya mencionado uso de los dos puntos, o del punto y coma. Nada enseña más que comprender la mecánica interna de una novela admirable, así uno nunca vaya a usar los elementos descubiertos en ellas, pero sí otros, pues nos informa sobre el tipo de argucias que son claves para sostener una narración, enriquecerla, hacerla ágil, acentuar la curiosidad, detenerse de repente en un elemento descriptivo, etc. Si uno se acerca demasiado a su esquema el parecido salta a la vista, al menos a los lectores atentos. Es lo que ocurre, en mi opinión, con Abril rojo, de Santiago Roncagliolo (muy cerca en personajes y trama y en el lenguaje de Lituma en los Andes), o sin ir más lejos con mi primera novela, Páginas de vuelta - que el tiempo con su sabiduría ha ido borrando (el acercamiento a la ciudad, los personajes)—. También veo esto en las ya mencionadas Tinta roja y Últimos días de La Prensa (muy parecidas en su vivencia periodística a La tía 
Julia) o con Río Fugitivo, la primera novela del boliviano Edmundo Paz Soldán, donde se percibe la música vargasllosiana en un uso específico del estilo indirecto libre combinado con diálogos. No es casual que todas tengan en común el ser primeros trabajos de autores que luego reforzaron sus voces, lo que muestra cómo la transitoria influencia de Vargas Llosa no es algo que suplanta la propia escritura sino que, al contrario, la estimula.

Esto es tan palpable que el mismo Vargas Llosa, sin duda consciente, decidió facilitar aún más las cosas a los aprendices y escribió para ellos Cartas a un joven novelista, donde expone con su habitual claridad y lujo de ejemplos cada uno de los puntos fundamentales para que una narración exista y flote. Otro texto suyo en donde revela muchas de las armas indispensables para la escritura es La verdad de las mentiras, una conferencia que transformó en prólogo a un libro en el que reseña 25 grandes novelas del siglo XX. Ahí, Vargas Llosa, siempre guiado por una pulsión que es a la vez militante y pedagógica, explica la distancia entre las novelas y la vida, el uso de las propias experiencias y el modo en que éstas se van introduciendo en la obra, sin que esto convierta al autor en un notario de sí mismo o en un biógrafo delante del espejo.

\section{La ciudad}

Ya mencioné más arriba el modo en que la estética de Vargas Llosa se adapta extraordinariamente a la narrativa urbana contemporánea, y cómo es muy natural que los jóvenes narradores latinoamericanos, la mayoría nacidos en ciudades, hayan visto un modelo cercano en su escritura. Por supuesto que no todos los libros de Vargas Llosa pueden clasificarse como narrativa urbana. Ni La casa verde, ni Lituma en los Andes, ni Pantaleón y las visitadoras lo son. Pero sí La ciudad y los perros, Los cachorros, Conversación y La tía Julia. Y son suficientes. La literatura peruana ha sido tradicionalmente una de las más ricas en narrativa urbana. Vargas Llosa tuvo como antecedentes a dos verdaderos maestros, Julio Ramón Ribeyro y Sebastián Salazar Bondy. De Ribeyro, Vargas Llosa leyó de joven Los gallinazos sin plumas (1955) y Cuentos de circunstancias (1958), historias a veces tristes y a veces jocosas de gente común y corriente que deambula por las mismas calles limeñas por las que transcurría su vida, llegando a establecer una suerte 
de equivalencia entre esas vías atestadas de automóviles, fachadas sucias y ruidos, con los sueños apolillados de sus transeúntes; algo similar leyó en el Bondy de las Estampas limeñas y posteriormente en Lima la horrible.

De estos antecedentes nace algo rabiosamente urbano y es la épica del hombre de la calle, el ciudadano gris que sube a los buses, entra a los hospitales o se enamora de la efigie de una mujer en un cartel publicitario. También del hombre derrotado, nihilista. Del hombre sin atributos. Vargas Llosa, con su literatura urbana, conecta - al igual que Carlos Fuentes, en México- con la gran vanguardia de la novela europea y norteamericana que busca descifrar el alma humana a través de la experiencia de la metrópoli, de las derrotas, alegrías o pequeñas tragedias de seres anónimos - la ciudad es el territorio del anonimato-, y que produjo obras inmensas como Berlin Alexanderplatz, de Döblin, Manhattan Transfer, de Dos Passos, o Ulises, de James Joyce. La conexión literaria con esta vanguardia hace de Vargas Llosa un autor muy moderno, que toma una tradición y la aplica a su mundo, y que al hacerlo abre puertas y las deja abiertas para otros.

En el caso de los autores colombianos de mi generación, que no tuvimos un referente urbano en nuestra literatura, no es de extrañar que la mayoría nos hayamos volcado sobre las novelas de Vargas Llosa o Carlos Fuentes, en busca de un antecedente. Colombia tuvo muy poca novela urbana y esto tal vez se deba a que ninguna ciudad, ni siquiera la capital, se destacó notoriamente de las otras para convertirse en el gran polo de atracción, en el objetivo de los anhelos y deseos de todos, y por lo tanto cuando un joven escritor de provincia llegaba a Bogotá, a Medellín o a Cali, se dedicaba más bien a escribir sobre el mundo rural que había dejado atrás, pues nada lo deslumbraba, nada lo hacía sentir que entraba a otra dimensión. Bogotá, para Colombia, jamás significó, ni de lejos, lo que representa México D. F para México, Lima para los peruanos o Buenos Aires para los argentinos. Un ejemplo de este curioso fenómeno: García Márquez estuvo de joven en Bogotá y vivió nada menos que el asesinato del líder liberal Jorge Eliécer Gaitán —9 de abril de 1948 - y la revuelta posterior que llamamos "el Bogotazo", en el que una masa enardecida de dolor se volcó contra el gobierno y sólo durante el primer día hubo 3.500 muertos y la destrucción de gran parte del centro histórico de la capital. Pero esta experiencia, que podría haber sido reveladora para otro escritor, a García Márquez no le atrajo li- 
terariamente, y la prueba es que nunca escribió sobre ella, jamás tuvo la necesidad o la tentación de interrogar ese hecho, crucial para la historia moderna del país, con las herramientas de la literatura, pues su mundo literario estaba situado muy lejos, en un pueblecito de la costa atlántica, y esa lejanía, por muchos avatares que ocurrieran, no hacía más que reforzarla.

De ahí que las primeras novelas urbanas en Colombia, escritas en mi generación, lleven los sellos de Vargas Llosa y Carlos Fuentes. ¿Dónde más íbamos a encontrar ficciones en las que los personajes se presentaran a sí mismos a través de su habla, sus chistes o exabruptos, y que al hacerlo fueran dibujando un tejido social, una forma peculiar de estar en el mundo, la que confiere una urbe a sus habitantes? No teníamos antecedentes locales y eso dificultaba las cosas, pues al ritmo de cada ciudad hay una prosodia particular, la música que en cada una adquiere el español, y que es muy diferente en Lima, en Bogotá o en el DF, una distancia que nos dejaba frustrados y ponía más barreras aún entre nuestras experiencias y el modo en que queríamos contarlas, al punto de que, con algunos amigos aspirantes a escritores, un día, bastante derrotados por el vacío de experiencias escritas previas a las nuestras, llegamos a la conclusión de que Bogotá era una ciudad refractaria a la literatura, y la decretamos terreno baldío, espacio muerto entre trincheras, tierra de nadie. Más adelante, con la terquedad pregonada por Vargas Llosa, los autores bogotanos fuimos encontrando el camino, y la ciudad, poco a poco, tuvo sus primeros retoños. No es casual que muy pronto, por cercanía temática, se haya derivado hacia la novela negra, que es por excelencia un género urbano en el que, además, se le puede dar rienda suelta a la influencia del cine.

Curiosamente ni Vargas Llosa ni Carlos Fuentes practicaron de forma muy contundente la novela negra. Vargas Llosa tiene ¿Quién mató a Palomino Molero?, un libro menor en el que transforma a su personaje Lituma en detective, y que además es en un pueblo de los Andes, y Fuentes La cabeza de la hidra, también un libro menor, con una trama más influenciada por las novelas de intriga anglosajonas, espionaje y desafíos a la seguridad nacional. Pero su aporte al impulsar la novela urbana abre definitivamente las esclusas para que generaciones posteriores, como la del mexicano Paco Ignacio Taibo II, desarrollen un nuevo subgénero que, con el tiempo, ha dado en llamarse "neopolicial latinoamericano", que sigue escribiéndose con éxito en casi todos los 
países, adecuándose en cada uno a las necesidades del género, absorbiendo los problemas de cada región y denunciando la violencia que brota aquí o allá, y que va desde la llamada literatura sicaresca del narcotráfico y sus asesinos a sueldo, en Colombia primero (Jorge Franco) y luego en México (Elmer Mendoza), hasta los crímenes ligados a las experiencias dictatoriales del cono sur.

\section{McOndo y Vargas Llosa}

Uno de los hechos que define a una parte de la generación de autores que empezó a publicar en los años noventa, en América Latina, es la aparición de la antología $M c O n d o$, hecha por Alberto Fuguet y Sergio Gómez, la cual presenta una serie de afirmaciones un poco alocadas y muy radicales sobre el tipo de literatura que se hacía en esos años - con el tiempo incluso Fuguet ha renegado de ellas-, pero con una idea de fondo que era cierta, y que consistía en que el realismo mágico, un estilo tan arrollador y exitoso, dejó como consecuencia que a un autor que proviniera de América Latina se le debía exigir, para ser visible en Estados Unidos, algún tipo de cercanía o parecido con él. Fuguet y Gómez hablan de una experiencia en Iowa, y la comprendo pues yo viví exactamente lo mismo en Europa. La primera vez que una editorial italiana consideró para traducción mi novela Perder es cuestión de método - pido disculpas al respetable por citar de nuevo algo mío, pero como se verá no es muy honroso-, acabó rechazándola con cajas destempladas con el argumento de que "el estilo es muy europeo", lo que me llevó a largas cavilaciones preguntándome ¿qué es el estilo europeo?, ¿el de España o el de Italia?, ¿el de Andorra o Liechtenstein? Por supuesto lo que la editorial quería decir era que mi novela no correspondía en absoluto al contenido que ellos esperaban de un autor latinoamericano, y para más señas colombiano, es decir el realismo mágico.

Una historia de argumento policial, ubicada en una ciudad latinoamericana y en la que se escenificaban la corrupción y la pérdida de valores, no les interesaba en absoluto. ¿Qué hubiera pasado si la imagen preponderante se hubiera formado a partir de las ficciones de Vargas Llosa y no de García Márquez? Aun si algunas de sus novelas sobre la selva y los Andes (La casa verde, Pantaleón, Lituma en los Andes) podrían ser adscritas a este imaginario vasto en donde el paisaje y sus excesos parecen ser los verdaderos protagonistas, ni el lenguaje ni la 
estructura ni el tipo de personajes de Vargas Llosa corresponden al realismo mágico, pues es una obra múltiple, que está en la selva pero también en París, que va de los playones de La casa verde a un restaurante lujoso de Tokio, de las guerras de Antonio Conselheiro a la conjura contra Trujillo, y por esto mismo, no sé si sea muy descabellado pensar que en la medida en que Vargas Llosa fue asentando más y más su mundo literario en Europa y Estados Unidos, la imagen de América Latina se fue haciendo menos estereotipada y más compleja, más cercana a su realidad también múltiple.

Cada vez que ese espacio de recepción se hacía más amplio, más cabida iban teniendo los autores de mi generación, los cuales presentaban en sus novelas, cuentos o ensayos, versiones de América Latina o de la vida, del mundo o de la literatura, que incluían diferentes ángulos, otras experiencias, un sentido nuevo del devenir, la incorporación de nuevas historias ligadas a los progresos de la técnica, a la conformación de las ciudades y sus diversas economías, a su paisaje humano, su violencia endémica que se transmuta y adquiere tremebundas máscaras, a los repentinos cambios políticos, en fin, a la vastedad de una experiencia continental que va y viene, como un banco de peces, y cuya imagen es siempre impredecible.

De hecho, el autor de mi generación - aunque esto puede ser discutido - que de nuevo volvió a proyectar con fuerza una imagen de Latinoamérica en los grandes escenarios mundiales, Roberto Bolaño, está diametralmente alejado del realismo mágico, y más bien se ubica en un estilo que contiene a las vanguardias europeas, sobre todo francesas, y una escritura en la que a menudo predomina el diálogo, uno de los elementos centrales de la estética de Vargas Llosa. Comprobando que en el estilo de Bolaño no hay huella de realismo mágico, y ante la evidencia de su extraordinario éxito internacional, se puede afirmar que, desde el punto de vista de su recepción literaria, América Latina ya pasó la página: lo que se espera hoy de un narrador de este continente no es un sólo tipo de fábula sino muchos.

En ese espacio abierto por novelistas como Vargas Llosa, pero también por Fuentes y Cortázar, entre otros, cabe todo. Todas las mezclas (¡todas las sangres!) y experimentaciones están permitidas. Bienvenidas sean. Lo vemos en los autores de la ya mencionada antología de McOndo o en los del Manifiesto del Crack - de los escritores mexicanos Jorge Volpi, Ignacio Padilla, Pedro Ángel Palou y Eloy Urroz-, 
así como en otros escritores que no formaron parte ni de uno ni de otro - caso de Bolaño-, o de los que llegaron después, como la llamada generación del "Bogotá 39". Hasta los más rabiosamente vanguardistas caben en este espacio, pues todos han establecido lazos de continuidad $\mathrm{y}$ en sus obras siguen respondiendo a una tradición latinoamericana de universalismo, síntesis de culturas propias y ajenas, y algo que aún podríamos llamar "experiencia postcolonial", que en el fondo es una de las pocas grandes riquezas de nuestra historia. 